\title{
O ROMANCE BRASILEIRO: MACHADO DE ASSIS*
}

\section{Barreto Filho}

\begin{abstract}
Resumo: Em "Esquema de Machado de Assis", ensaio no qual Antonio Candido faz uma síntese precisa sobre a história da recepção crítica da obra machadiana, o crítico identifica na década de 1940 uma tendência às leituras pelo viés da filosofia cristã, que enfatizou a angústia existencial do homem e do escritor, sentimento que teria repercutido de maneira decisiva sobre a obra. No interior dessa vertente, Candido destaca Barreto Filho como um dos melhores, e seu livro, Introdução a Machado de Assis, de 1947, como "uma das interpretações mais maduras que possuímos de sua obra".
\end{abstract}

Mais de seis décadas após a publicação de sua Introdução, continuam a impressionar a consistência, a coerência e a sensibilidade dos escritos de Barreto Filho. Leitor amoroso e muito bem informado pelos principais estudos biográficos e críticos publicados até então, como os de Alfredo Pujol e Lúcia Miguel Pereira, Barreto Filho recompõe no livro o percurso completo do homem e do escritor, da infância à morte, dos primeiros versos publicados na década de 1850 ao último romance, o Memorial de Aires, de 1908.

Para refazer essa trajetória, lança mão também de seus conhecimentos de psicologia e psicanálise - Barreto Filho foi professor de psicologia da educação no Rio de Janeiro - de modo a construir sua própria interpretação do autor e seus escritos e, nas suas palavras, "descobrir a ligação que há entre a obra e o homem".

Tendo à disposição a imensa quantidade de dados e interpretações levantadas por grandes pesquisadores da obra machadiana por ocasião das comemorações do centenário de nascimento, em 1939, Barreto Filho faz uso de uma imaginação crítica e psicológica apurada para reconstituir a infância do escritor, sobre a qual restou pouquíssima documentação, e identifica na orfandade precoce de Machado a origem de um espírito trágico:

"Não é o céptico ou o humorista, que mais interessaram no seu tempo, o aspecto dominante e duradouro da sua obra, mas o seu espírito trágico no sentido antigo, dominado pela sensibilidade do inexorável."

Sem jamais impor suas convicções pessoais sobre o escritor ou a obra, Barreto Filho valoriza em Machado justamente as diferenças, aquilo que não compreende no homem, no escritor e na obra. Esse fascínio pela irredutibilidade do outro a categorias ou sistemas pré-

\footnotetext{
* Este texto é parte do capítulo dedicado a Machado de Assis no livro O romance brasileiro: de 1752 a 1930, organizado por Aurélio Buarque de Holanda (Rio de Janeiro: O Cruzeiro, 1952. p. 132-150).
} 
determinados move sua crítica generosa e atenta, que não procura aplacar com certezas a perplexidade que a leitura de Machado lhe transmite.

Num momento em que parte importante da crítica procurava especificar as relações entre o humor machadiano e as influências inglesas de Swift, Shakespeare e Sterne, o crítico de ouvidos aguçados buscava as raízes do humorismo de Machado no ambiente brasileiro e carioca:

"As suas fontes são a pilhéria, a maledicência, a anedota carioca, essa coisa quase indefinível que já se cristalizara no espírito da capital, uma espécie de gracejo, menos pesado que a farsa, menos inteligente que a ironia, menos grosseiro que a facécia, e que podemos encontrar em outros escritores nossos, como Carlos de Laet, por exemplo."

A observação aguda sobre a fonte carioca do humorismo de Machado talvez se deva também à trajetória do crítico que, nascido em Aracaju em 1908, se mudou para o Rio de Janeiro ainda na adolescência. Em 1922, aos 14 anos, portanto, já estava no Rio, onde publicou o livro de poemas Catedral de oiro. Sua carreira como escritor, no entanto, começara em Sergipe, ainda mais precocemente, quando menino. Ao longo da vida publicaria ainda um romance que marcou época, Sobo olhar malicioso dos trópicos (1929). Junto com Andrade Murici, Tasso da Silveira e Cecília Meireles, participou no Rio de Janeiro do grupo Festa, de tendência espiritualista.

No ensaio que aqui se publica, "O romance brasileiro: Machado de Assis", os leitores terão oportunidade de conferir o talento crítico de José Barreto Filho, a quem a Machado de Assis em linha presta esta justa homenagem.

Os editores agradecem de público aos filhos e netos do crítico, que por intermédio da filha Maria Amélia Barreto Peixoto generosamente deram permissão para publicação deste artigo.

Palavras-chave: Barreto Filho; romance; humor.

\title{
The Brazilian novel: Machado de Assis
}

\begin{abstract}
The essay "O romance brasileiro: Machado de Assis", republished in this edition of Machado de Assis em linha, is a sample of José Barreto Filho's critical talent, to which Machado de Assis em linha pays homage. As the reader will see, Barreto Filho never imposes his personal views on Machado and his works. Instead, he seems to value exactly what he cannot understand in the man, the writer and his writings. The fascination with the other's irreducibility to predetermined categories or systems is the main characteristic of his generous and attentive critique. Writing in a moment when many critics tried to specify the connections between Machado's humour and the influences of Swift, Shakespeare and Sterne, Barreto Filho
\end{abstract}


pricked up his ears to find the roots of the writer's humour in Rio de Janeiro, an example of the independence and originality of his critique.

Keywords: Barreto Filho; novel; humour.

Existe entre o conto e o romance uma diferença de estruturação interna, que solicita aptidões peculiares e todo um aparato distinto de atitude mental. O conto é a fixação de um incidente significativo, é por natureza sintético e especializado a um momento que se isola no curso da vida. O resto do tempo, do passado e do futuro de seus personagens, é sugerido ou indicado, simplesmente como uma contribuição ao sentido desse momento ou dessa situação privilegiada. Tem um caráter estático e é mais a contemplação mental de relações essenciais entre as coisas e os seres, do que a recriação de uma corrente de vida, com o seu volume integral em pleno movimento. Os personagens, nele, podem ser tratados por um processo de esquematização, dominados de perto pelo trabalho de elucidação intelectual, que se projeta de um só jato, e é excepcionalmente favorável a essa modelagem breve, inteligente, que se prestou mais facilmente à maturação técnica e expressional de Machado.

O romance inclui muitas dificuldades de estilo comuns aos contos, mas lhes acrescenta outras, que lhe são próprias e que exigiram do escritor, para serem superadas, certos sacrifícios de um sentimento de poesia, de um veio lírico que ele pode integrar nas composições de estilo menor.

O romance, e isso resume, grosso modo, as dificuldades secundárias, é antes de tudo um largo movimento. A vida deve ser aí simplesmente recriada e não somente interpretada. Admite-se que essa recriação seja feita através do comentário: foi o caso singular de Proust; mas é necessário que o resultado consiga reproduzir a vida de uma criatura que seja, com todas as repercussões virtualmente ilimitadas que a relacionam com o universo. Um personagem de conto pode ser uma aparição autônoma; o do romance é intrinsecamente relacional, carrega consigo um sem-número de relações ou de possibilidades delas. Daí a exigência de uma dramatização, de um desenrolar no sentido do tempo, que imprime aos personagens e aos acontecimentos um caráter 
histórico. O conto participa mais do intemporal; a substância mesma do romance é a duração, e daí o seu valor eminente, que não revela somente o essencial, mas a existência concreta, com as suas últimas determinações. O conto é uma linha melódica; o romance, uma estruturação harmônica.

As primeiras tentativas de Machado no grande gênero possuem hoje um restrito interesse documental. Apenas nos esclarecem, como realizações completamente frustradas. São elas Ressurreição, A mão e a luva, Helena e Iaiá Garcia.

Em Ressurreição, que, se tivéssemos de escolher, ainda preferiríamos entre os livros dessa fase, Machado já está de posse da orientação que deve tomar: ele próprio nos adverte que não faz romance de costumes, mas de caracteres, percebendo desde logo a mudança que terá de operar para instalar a feição de seu espírito em seu máximo rendimento. O livro é, de fato, uma tentativa nesse sentido, e já nos oferece certas passagens de tensão psicológica, que agradam. Tem a vantagem, sobre os seguintes, de uma unidade e condensação maiores, que veio a perder nos outros três pela preocupação de alargar o tecido de relações e o volume de vida, experimentando um processo para ele impraticável. Ressurreição é um conto alongado, e ainda beneficia da simplicidade breve desse gênero; os outros já o serão cada vez menos, numa marcha progressiva para a dramatização, que não o poderia levar a parte alguma, e de cujo impasse veio salvá-lo o encontro com os humoristas anglo-saxões. (Ver, de Eugênio Gomes, Influências inglesas em Machado de Assis.)

Não há dúvida que já se podem observar, em todos eles, os prenúncios do futuro Machado, a procura de uma nova técnica. (Ver o capítulo "Um rival", em A mão e a luva.) Tudo isso, porém, eram meros detalhes, que nada podiam produzir de decisivo enquanto se não modificasse a atitude mental, que permanecia inerte e sem estímulo em face do modelo romântico. Será em vão que Machado se impregnará de um romance narrado, como por exemplo $O$ tronco do ipê, de Alencar; a sua inteligência precisa de outro estímulo, possui um aspecto perverso que lhe constitui precisamente a modernidade, e que exige uma atitude mental radicalmente diversa.

É essa inércia mental que ele registra em Iaiá Garcia, quando Jorge, lembrando-se uma vez de escrever um romance, que era nada menos que o seu próprio, "ao cabo de algumas páginas reconheceu que a execução não correspondia ao 
pensamento e que não saía das efusões líricas e das proporções da anedota" (capítulo VII). Machado, porém, insistia.

Com o Brás Cubas surge inopinadamente a mudança de rumo. Parece que Iaiá Garcia completara um ciclo, e o capacitara de que a máxima perfeição que lhe era possível conseguir naquela direção não era de maneira alguma convincente.

É possível que a moléstia que o antecedeu, e que parece ter sido grave (ver Lúcia Miguel Pereira), tivesse precipitado a maturação de processos técnicos que ele vinha ruminando, e talvez lhe houvesse suscitado o estado de espírito, o ângulo de visão, que lhe era propício. É como se lhe houvessem ameaçado a segurança pessoal, e ele reagisse amargo e ferino contra forças injustas e incoerentes. Pode-se procurar a explicação desse incidente moral em um dos trechos do próprio Brás Cubas: "E contudo era eu, nesse tempo, um fiel compêndio de trivialidade e presunção. Jamais o problema da vida e da morte me oprimira o cérebro; nunca até esse dia me debruçara sobre o abismo do inexplicável; faltava-me o essencial, que é o estímulo, a vertigem [...]" (capítulo XXIV).

Esse estímulo, para Brás Cubas, fora a morte da mãe; para Machado poderia ter sido a própria ideia de morte, encarada como possível, experiência que nenhum homem faz profundamente antes de uma certa idade. A nossa natureza é organizada de tal sorte que essa ideia é uma das mais abstratas e longínquas, e se é admitida pela nossa inteligência, nunca o é pelos nossos tecidos, antes que eles próprios comecem a envelhecer.

Como quer que seja, o fato é que um estímulo súbito coloca Machado em condições de reatividade violenta, que libera, em atropelo, todo um aparelhamento de expressão assimilado em silêncio e mobilizado de repente. Reivindica de um golpe aquela "forma livre" que o dispensa das regularidades do romance normal e que the permite destilar em torno da ação e através da ação os hormônios acerbos de sua inteligência. É a desenvoltura de quem está afinal pisando em terreno firme e quer experimentar as suas forças em todos os sentidos. É o alvoroço de "uma obra séria", que o Pestana não pudera obter, embora "supinamente filosófica, de uma filosofia desigual, agora austera, logo brincalhona, cousa que não edifica nem destrói, não inflama nem regela, e é todavia mais do que passatempo e menos do que apostolado" (capítulo IV). 
É esta "filosofia", com as suas pretensões niilistas e sombrias, que levanta afinal o tom do escritor e faz o livro sair "das proporções da anedota".

Os amores de Brás Cubas e Virgília, que são afinal de contas todo o conteúdo da narração, encontram-se relacionados a complicações metafísicas, a incidentes e diversões variados, que dão a ilusão da complexidade.

Há uma verdadeira orgia de processos técnicos incluídos nessa "forma livre", para sustentar, ampliar e emprestar complexidade à narração. Muitos são legítimos, muitos são supérfluos e ingênuos. O humor e a malícia nem sempre são do melhor quilate ("preferi dormir, que é um modo interino de morrer" - capítulo XIX). Abuso do jogo de palavras, como na história do tártaro, no capítulo LXIX. Sobretudo nota-se o gosto de certos paralelismos, de certas constâncias dos personagens subsidiários, que os tornam abstratos, porque representativos de certos traços de caráter exclusivos: o tio cônego e o tio oficial têm sempre opiniões opostas, determinadas pelas suas funções sociais (capítulos II e XVIII). A maioria desses personagens são puramente episódicos, de atuação escassa, a tal ponto que podem ser indicados muitas vezes como pertencendo a um capítulo, onde se fixaram, sem contribuírem propriamente para a narração, o que dá ao livro a aparência de uma galeria de tipos.

Existem episódios enxertados, e muitos de uma graça equívoca e barata, como são todos os que vão do capítulo XXXII até o XLIII, e alguns com enormes pretensões implícitas e injustificadas, como o de "A borboleta preta" (capítulo XXXI).

Citemos ainda, entre os recursos inaceitáveis inaugurados no Brás Cubas, certos truques literários que não saem da categoria de pilhérias: os capítulos feitos de pontinhos ("O velho diálogo de Adão e Eva", capítulo LV); o Lobo Neves rejeitando uma nomeação por ter sido feita no dia 13, e aceitando-a posteriormente num dia 31; o nome de Virgília surgindo-lhe da pena por coincidência ao escrever o virumque de um verso latino, e um sem número de impropriedades e impertinências inculcadas subrepticiamente de mistura com as aquisições autênticas. Não era ainda ocasião para selecionar.

Absolvendo-o de todas essas irregularidades, perpassa através do livro uma espécie de cinismo literário que descobre todos os truques, os ironiza e se adianta à 
crítica possível, funcionando como um álibi permanente, uma licença ilimitada às iniciativas do escritor.

Colhamos alguns exemplos. Depois de propor algumas comparações para uma ideia fixa: "Veja o leitor a comparação que melhor lhe quadrar, veja-a e não esteja daí a torcer-me o nariz, só porque ainda não chegamos à parte narrativa destas memórias. Lá iremos. Creio que prefere a anedota à reflexão, como os outros leitores, seus confrades, e acho que faz muito bem." (capítulo IV)

E vejam agora com que destreza, com que arte faço eu a maior transição deste livro. Vejam: o meu delírio começou em presença de Virgília; Virgília foi o meu grão pecado da juventude; não há juventude sem meninice; meninice supõe nascimento; e eis aqui como chegamos nós, sem esforço, ao dia 20 de outubro de 1805, em que nasci. (Ver o resto do capítulo IX, "Transição")

Para atenuar a gravidade do final da página anterior: "Ui! Lá me ia a pena a escorregar para o enfático" (capítulo XXV).

Pondo o álibi em relevo: "tu amas a narração direita e nutrida, o estilo regular e fluente, e este livro e o meu estilo são como os ébrios, guinam à direita e à esquerda, andam e param, resmungam, urram, gargalham, ameaçam o céu, escorregam e caem [...]" (capítulo LXXI)

Para se desculpar de um trecho excelente e sério, que é uma "afirmação desdenhosa de nossa liberdade espiritual" em face da multidão, apressa-se em acrescentar: "Vive Deus! Eis um bom fecho de capítulo" (capítulo XCIX).

Nesse trabalho de prevenir e desarmar a crítica, Machado toca num ponto nevrálgico, manifestando a argúcia pasmosa de seu espírito em tudo o que se relaciona com os processos de construção literária: "Capítulos compridos quadram melhor a leitores pesadões; e nós não somos um público in-folio, mas in-12, pouco texto, larga margem, tipo elegante, corte dourado e vinhetas... principalmente vinhetas [...] Não, não alonguemos o capítulo." (capítulo XXII) No Dom Casmurro ele fará a apologia dos livros omissos, melhores que os confusos, porque as suas lacunas podem ser preenchidas pela imaginação do leitor (capítulo LIX). 
A importância do trecho das vinhetas decorre de que ele se refere a processo estático, sem dinamismo, como uma série de instantâneos independentes, simplesmente justapostos. A armadura do Brás Cubas é mesmo essa, se abstrairmos os seus revestimentos. Machado ainda continua preso a esse atomismo da visão, e falta-lhe solucionar a questão da duração e da solidariedade das partes, que é indeclinável no gênero.

Em Brás Cubas esses instantâneos se põem em movimento e continuidade por uma ilusão cinemática: o comentário inteligente os aciona e lhes serve de argamassa, não tanto, porém, que a sua junção e fluência resultem tão concluídas que não se notem os excessos, os materiais desgarrados, as soluções de continuidade e os passos incertos.

Passam por esses interstícios estímulos de distração que perturbam a estabilização de uma atmosfera de credibilidade; fica-se dependendo mais do espírito do autor do que do interesse da narração; a sua virtuosidade a asfixia, e, paralela a esta, instala-se um prazer por demais gratuito e inconsequente para ser realmente artístico.

Dentro disso, porém, que riqueza de vida interior, que maravilhosas invenções para registrar as peripécias da consciência e os frêmitos da alma! Como ele sabe conceituar essa "geologia moral", formada pelas "camadas de caráter, que a vida altera, conserva ou dissolve, conforme a resistência delas" (capítulo LXXXVII)! Como é segura e concisa, por exemplo, aquela página - "Compromisso" -, elucidação perfeita e simples de um momento psicológico que toca ao indefinível!

Virgília já se inscreve entre as grandes figuras femininas de Machado, e D. Plácida comove e convence, com a sua capitulação insensível a um ofício repugnante.

Brás Cubas, como já vimos, acha-se, além disso, sobrecarregado de uma superestrutura "filosófica", que encontra também o seu álibi no modo de tratar Quincas Borba, o filósofo do humanitismo. A figura do filósofo é curiosíssima, e a sua teoria aparece naturalmente como uma sátira. Era de prever que assim fosse, porque Machado, esquivando-se sempre ao enfático, raramente desenha uma cena séria que não lhe atenue a ênfase possível com uma pilhéria ou ironia (o que muitas vezes reforça a sua seriedade e o seu efeito, como, entre tantos outros, o episódio do Manduca, em Dom Casmurro). Pelo mesmo motivo não ousaria nunca integrar num romance uma concepção 
"filosófica", sem cercá-la de todos os corretivos e contrapesos (inclusive a loucura de seu representante), que a transformam finalmente numa sátira.

Creio, porém, que em parte pode ser tida como uma tentativa, a sério, embora frustra, para alcançar a explicabilidade do universo. Veja-se em Quincas Borba, que se seguiu a Brás Cubas, o trecho do capítulo VI: "- Não há morte. O encontro de duas expansões, ou a expansão de duas formas, pode determinar a supressão de uma delas; mas, rigorosamente, não há morte, há vida, porque a supressão de uma é a condição da sobrevivência da outra, e a destruição não atinge o princípio universal e comum."

Convenhamos que a coerência da demonstração trai pelo menos uma certa conivência do escritor em face da teoria. Nessa e ainda noutras passagens, em que se relaxa a pressão irônica a que ele submete continuamente os temas, transparece de maneira muito fugaz, exigindo grande atenção de quem pretende surpreendê-lo, um início de aceitação daquilo que ele parece recusar irremissivelmente. Machado velou, dessa maneira, muitas veleidades de convicção, de entusiasmo e de comoção, por um singular pudor de quem não se sentia autorizado a esses movimentos. É assim que, no Memorial, nós encontramos a história de um cachorrinho do Aguiar, enterrado no fundo do quintal, pela ternura daquele casal sem filhos. O Aires registra o fato no Memorial e acrescenta: "Não faltam cães atrás da gente, uns feios, outros bonitos, e todos impertinentes." (18.09.1888)

Sabe-se que essa história se deu com o próprio Machado, e o protesto de inimizade com os cães, ou mesmo de indiferença, não é mais do que um álibi que prepara para si mesmo. Muitas coisas nesse escritor de mil mascaras se esclarecem, se tivermos presente na memória este aforismo: Machado de Assis, como escritor, é um exímio preparador de álibis para o homem. E este último beneficiará certamente de uma compreensão orientada nesse sentido.

No Brás Cubas, em que ele descobre muitas vezes as suas baterias, poderemos entrever uma crise de espírito, dessas que podem deslocar a consciência para a reflexão dos problemas transcendentes. A sua evolução, porém, parece ter sido truncada, não só por condições personalíssimas do escritor, entre as quais a sua ausência de vocação para o esforço transcendente, como também por circunstâncias extrínsecas, do tempo e do meio. Machado entrou em contato com um movimento de ideias cujo valor metafísico é 
fácil de averiguar pela facilidade com que se prestou a ser traduzido quase fielmente, nas suas linhas gerais, pelo humanitismo de Quincas Borba. Grande leitor de Spencer e certamente de Comte, respirou a atmosfera metafísica de um evolucionismo que anulava o indivíduo, como um acidente sem importância no devenir universal, e que ainda lhe exigia um grande entusiasmo e otimismo pelo fato de ser vivido por uma entidade superior - natureza ou sociedade. Machado, se tinha de admitir os princípios filosóficos, pelo menos se recusava, e com razão, às exigências éticas, e achou que a vida assim não tinha lá perspectivas muito prazenteiras, nem um sentido definido. Achou que o fruto do reconhecimento era amargo e que o homem não tinha motivos para continuar mergulhado no otimismo do século XIX. Terá entrado por fim a superar pela ironia essa construção intelectual que entrava em tão doloroso conflito com a sua vontade de ser ele mesmo, e por aí deixou em suspenso todas as irresoluções de que se viu cercado. A sua afirmação de permanência propunha um ponto de partida que ele não pode desenvolver, e que vem expresso no delírio de Brás Cubas, quando ele exclama para Pandora: "Viver somente, não te peço mais nada. Quem me pôs no coração este amor da vida, senão tu? E, se eu amo a vida, por que te hás de golpear a ti mesma, matando-me?" (capítulo VII).

A reflexão de Machado de Assis não era de têmpera metafísica, afloravam dentre os problemas dessa categoria apenas aqueles que são indeclináveis a todo esforço de reflexão moral que alcança um certo grau de generalidade. O problema da vida e da morte, do bem e do mal estão vivos, e tanto mais virulentos quanto não ainda definitivamente domados pelo equilíbrio exíguo que ele conseguiu depois, e consistiu numa limitação voluntária, um tanto ressentida, que bem pode ser expressa por uma de suas frases em A mão e a luva: "- A experiência da vida [...] devia ter-me convencido de que o melhor de todos os sentimentos é um egoísmo quieto e calado." (capítulo X)

Na época ele Brás Cubas, porém, parece que a crise de maturidade o encontrou ainda incapaz de fazer funcionar perfeitamente todos os freios que uma tal atitude implica, e a reação desordenada do livro trai o profundo ressentimento, expresso na sua última frase, em parte feita para causar impressão, e muito mais romântica do que se pensa: "Não tive filhos, não transmiti a nenhuma criatura o legado de nossa miséria." Estava na hora dele acrescentar: "Vive Deus! Eis um bom fecho de livro"... 
Brás Cubas é um livro disforme, que não vale nenhum dos que a ele se seguiram. Pode ter sobre um único - Esaú e Jacó - a vantagem de uma cintilação e de um tumulto que falta a esse livro árido de Machado. Essa cintilação, porém, como vimos, é muitas vezes de origem duvidosa, e não é capaz de compensar-se com o estado de maturação e as linhas assentadas do outro.

Quincas Borba é um livro muito mais rico de vida e de substância humana do que o anterior. Sente-se que a crise mental já foi superada, para dar lugar a uma atitude de tranquilo desafio diante do mistério, tal qual como aquele mendigo diante do céu, no largo do Rossio:

Olhavam-se numa espécie de jogo do siso, com certo ar ele majestades rivais e tranquilas, sem arrogância, nem baixeza, como se o mendigo dissesse ao céu:

- Afinal, não me hás de cair em cima.

E o céu:

- Nem tu me hás de escalar. (capítulo XLVI)

Estabelecido esse compromisso, a condição do homem se assemelha à atitude do estoico, que não abdica do direito de afrontar o destino, perseguindo o ideal de sua perfeição humana. Um "egoísmo quieto e calado", incluindo os prazeres austeros e simples, como o seu casamento com Carolina, e o convívio de alguns amigos bastariam para compor uma vida, no que se refere ao cotidiano; e a grande paixão literária, a modelação de tipos, oferecia uma possibilidade de canalização para as forças excedentes.

É um livro de grande comoção e piedade humana, o único em que se percebe um movimento de cordialidade para com as suas criações. $\mathrm{O}$ antagonismo do escritor para com elas é discreto e reduzido ao estímulo rigorosamente necessário à viabilidade da obra na sua sensibilidade. Deixa-as, porém, viver, de uma vida mais ampla que a de muitos dos seus personagens, que à força de realizarem um certo tipismo moral acabam por ser os índices abstratos de uma equação, que o autor transforma com a sua consumada habilidade.

É o livro mais desprevenido de Machado, mais ventilado, onde as correntes humanas perpassam com maior desembaraço e amplitude, sem aquela dosagem 
meticulosa que autorizou Raul Pompeia a dizer que ele era "um escritor correto e diminuído". Tem muito pouco de inglês na sua tonalidade geral, e a própria excentricidade do filósofo louco e de sua filosofia, que pode passar como tendo um cunho britânico, já se encontra aqui atenuada, diluída numa comoção humana e local que lhe retira o ácido sabor com que apareceu em Brás Cubas. Talvez que o humanitismo voltasse banhado dos ares autóctones das montanhas de Minas, onde o filósofo foi encontrar o seu único discípulo.

O interesse do livro se traslada para a ação e para vida e se concentra nas duas figuras realmente admiráveis de Rubião e de Sofia. Ambas nada têm de saxão; lembram muito mais influências francesas, as belas figuras de mulher de Balzac e a grandeza e decadência de seu César Birotteau.

A autenticidade das duas criações, a felicidade do momento de concebê-las e traçá-las, revela-se no movimento inicial que elas assumiram por si mesmas, escapando à habitual ditadura daquele autor inteligente em excesso. Machado resmunga, impacienta-se com a genuína bondade de Rubião, mas afinal deixa-o viver e ser como é: um coração generoso e inocente, que a grandeza embriaga, não por si mesma, mas porque emoldura a beleza, essa cálida e maliciosa beleza das mulheres de Machado, encarnada aqui num de seus mais magníficos exemplares.

Foi um de seus segredos, esse poder de evocação da alma e do corpo femininos, poder que lhe vinha talvez de um sensualismo larvado, que se espiritualizou à custa de timidez e êxtase contemplativo: "amor adolescente e virgem, retido pelos liames sociais e por um sentimento de inferioridade que o impediu de reconhecer-se a si mesmo" ("Uns braços"). O episódio de um movimento sensual contido acha-se modulado em toda a sua obra e lhe deu acesso ao mistério feminino, que não se revela aos frios nem aos saciados, mas aos que podem transformá-lo numa força imaginativa que se alimenta mais da contemplação e do sentimento da forma do que propriamente do contato. Quando ele descreve Sofia, o tom alcança um lirismo forte, como o do seguinte trecho, revestido de uma absoluta modernidade de expressão:

Rubião admirou-lhe ainda uma vez a figura, o busto bem talhado, estreito embaixo, largo em cima, emergindo das cadeiras amplas, como uma grande braçada de folhas sai de dentro de um vaso, a 
cabeça podia então dizer-se que era como uma magnólia única, direita, espetada no centro do ramo. (capítulo XXXVII)

A figura de Sofia é talvez a mais magnética das aparições femininas de Machado. Capitu é muito astuciosa; Fidélia, muito grave e serena; Virgília se desimanta pela facilidade do temperamento. Sofia está enervada mediante contradições internas, entregue a fatalidades temperamentais que se completaram com as do marido, tocado pela insânia de exibi-la. Veja-se a situação do capítulo CXLIV, entre Sofia e o marido, o declive que toma a excitação de Cristiano, e a colaboração pessoal de Machado, referindo-se a um pedaço do corpo de Sofia: "De feito, era um belo trecho da natureza."

A fatalidade do temperamento do marido fica inteiramente transparente, e a de Sofia é até formulada expressamente: "Se hás de amar a alguém, fora do matrimônio, ama-o a ele, que te ama e é discreto." (CXLI) Isso lhe diz uma das rosas que dialogam, objetivando a sua cisma interior, o jogo de suas veleidades íntimas (a veleidade foi um tema que obcecou Machado de Assis).

Essas duas fatalidades conjugadas marcam esses dois seres de um cunho de risco permanente, que já não se resolve tão simplistamente pela consumação, bordada a comentário, de todas as virtualidades do mal. Sofia não será nem de Rubião nem de outro, embora se pressinta que teria ido para Carlos Maria, se este fosse mais obstinado, ou para Rubião, se este fosse menos ingênuo. É que o nosso autor não está mais fazendo silogismos pelo gosto de ser arguto, e deixa à psicologia dos personagens toda a incerteza que eles comportam. O conselheiro Aires exprimirá mais tarde essa relação entre temperamento e ocasião: "- Não é a ocasião que faz o ladrão - dizia ele a alguém -, o provérbio está errado. A forma exata deve ser esta: 'A ocasião faz o furto; ladrão nasce feito'." (Esaú e Jacó, capítulo LXXV)

Isso foi uma conquista sobre o sestro por ele adquirido de julgar mal os personagens, conquista que é bem sensível na construção do tipo de Cristiano, marido de Sofia. É quando este, tendo envolvido Rubião numa sociedade comercial, começa a dificultar as suas retiradas, e propõe-lhe afinal uma liquidação. Tem-se a impressão de que o escritor vai claudicar, e conduzir a ação para uma catástrofe comercial, com a ruína de um Rubião defraudado pelo amigo. Creio mesmo que foi essa a primeira orientação de Machado. Dominou, porém, o seu sestro, em benefício evidente da figura 
de Cristiano, cujo egoísmo é muito mais sutil, e que desejou apenas esquivar-se à exaltação perdulária do outro, incendiada pela fascinação de Sofia.

A margem de compromissos e equilíbrios precários de que dispõe esta criatura singular, que justifica tão completamente a exaltação e por fim a loucura de Rubião, é magistralmente resumida, num pequeno capítulo que vale a pena transcrever:

\begin{abstract}
Assim, pois, o que parecia vontade imperiosa reduzia-se a veleidade pura, e, com algumas horas de intervalo, todos os maus pensamentos se recolheram às suas alcovas. Se me perguntardes por algum remorso de Sofia, não sei que vos diga. Há uma escala de ressentimento e de reprovação. Não é só nas ações que a consciência passa gradualmente da novidade ao costume, e do temor à indiferença. Os simples pecados de pensamento são sujeitos a essa mesma alteração, e o uso de cuidar nas coisas afeiçoa tanto a elas, que, afinal, o espírito não as estranha, nem as repele. E nestes casos há sempre um refúgio moral na isenção exterior, que é, por outros termos mais explicativos, o corpo sem mácula. (capítulo CLXIII)
\end{abstract}

Já estamos longe das janelas da consciência que têm o ofício de ventilá-la no Brás Cubas. O "ventilai as consciências, amigos, não vos digo mais nada" é uma pilhéria de que a gente gosta porque nos faz rir. Esse estudo moral é uma meditação austera, uma análise de diretor espiritual, e deixa à fragilidade humana todo o seu elemento trágico e comovente.

Se quisermos apoiar o paralelismo entre os dois livros, poderemos ainda contrapor os dois delírios, o de Brás Cubas e o de Rubião. A belíssima página em que o delírio de Rubião se exterioriza, dentro da carruagem, suporta a medida do trágico e é tecida com a lógica interna dos delírios e dos sonhos, de que Machado teve a intuição integral. O de Brás Cubas é um mero surto de virtuosidade, brilhante e sem conteúdo. O delírio de Rubião já está apontado à distância (como o caso de Capitu), em gestos e atitudes que não nos esclareceram no momento, mas que se precipitam agora, para nos transmitir o frisson suplementar de termos vivido junto ao estranho, dentro de sua atmosfera, sem que déssemos por isso. Lá está, por exemplo, aquele momento em que Rubião conversa com Sofia, ansioso a tímido: "Sofia, sentada no ângulo da janela, ia meneando os dedos. Rubião viu em duas rosas vulgares uma festa imperial, e esqueceu a sala, a mulher e a si." (capítulo CXLI) 
Machado não aceitou o conselho de amigos para completar a trilogia com um outro livro, que fosse ocupado por Sofia. Seria continuá-la e repeti-la, observa ele, tanto essa criação é independente de sua intolerância de autor e resultante da lógica interna dos acontecimentos. Isso só lhe foi possível como um triunfo sobre a sua virtuosidade e representa a reabsorção das técnicas acolhidas, que ficam em Brás Cubas num estado de suspensão.

Machado de Assis não quis repetir Sofia, e não repetirá mais, igualmente, esse não sei quê de arejado e de amplo que há nesse romance. Dom Casmurro e o Memorial, sem dúvida mais perfeitos, são livros "diminuídos", para falar como Pompeia. Não se trata de diminuição de valor; tem isso aqui o sentido do diminuendo em música, que modera o dinamismo e a intensidade, mas pode levar a um momento de maior interiorização. Machado volta, de instinto, ao seu modo menor, por meio de uma interiorização progressiva, que atinge no Memorial o caráter de uma música em surdina.

Vemos reaparecer em Dom Casmurro todo o aparato técnico de Brás Cubas, a inspeção inteligente do autor sobre os personagens, e até o sistema de pequenos quadros isolados cosidos pelas reflexões constantes do autor para reconstruir o movimento.

O domínio dos processos, porém, chegou ali a uma alta classe, e não perturba a inteireza da narração. Esta é um veio oculto, que vai correndo fora da nossa percepção imediata, mas em contato estreito com o nosso mundo de pressentimentos. O essencial é apenas induzido e se passa discretamente, tal como nos seus grandes contos ("Missa do galo", por exemplo). A utilização de um sistema de infiltrações pela consciência do leitor, mostrando o que ele quer fazer ver não diretamente no ponto em que se encontra, mas como uma refração indireta, o ambiente de insinuação constante e discreta, tudo se conjuga para sustentar o interesse e o enleio dessas páginas.

$\mathrm{Na}$ definição dos temperamentos de Capitu e de Bentinho, o processo se manifesta com toda a sua força convincente. Só pela qualidade dos sonhos respectivos fica definida a diversidade dos temperamentos (capítulo XII): os de Bento são realizações diretas de cenas da véspera - os sonhos de "tipo infantil", segundo a classificação de Freud; os de Capitu são todos entretidos pelos processos de "condensação", "transposição" e "dramatização", que lhes emprestam o ar de uma linguagem cifrada. Freud não viu melhor essas propriedades oníricas. 
No capítulo XVIII, em plena ameaça de seminário, Bentinho não deixa de comprar as cocadas habituais: "Comprei-as, mas tive de as comer sozinho; Capitu recusou. Vi que, em meio da crise, eu conservava um canto para as cocadas".

Enquanto esse sonhador se contenta em arquitetar planos impossíveis, envolvendo o próprio imperador, para fugir ao seminário que não era a sua vocação, esta, que era simplesmente Capitu, prefere soluções mais viáveis, apesar de sutis, e trava o surto imaginativo do outro: "- Não, Bentinho, deixemos o imperador sossegado." (capítulo XXXI) E é edificante a lógica de Capitu, alívio para o desespero e o ciúme de Bentinho, quando esta lhe explica que nem ao menos conhece, senão de vista, o rapaz que passou a cavalo: "Se olhara para ele, era prova exatamente de não haver nada entre ambos; se houvesse, era natural dissimular." (capítulo LXXVI)

E entretanto, apesar das múltiplas advertências semelhantes, nem o leitor nem Bentinho desconfiam das consequências inevitáveis que vão surgir da atualização dessas virtualidades. Por enquanto tudo isso serve apenas, a nós e a ele, para nos submetermos ao domínio de Capitu. É irresistível a sua atração, constituída justamente desses elementos duvidosos, que, introduzindo nela fatores de incerteza temperamental, criam por isso mesmo um estado de tensão interna que nos impressiona como uma força.

Tudo, porém, é maravilhosamente dosado, para insinuar e despistar ao mesmo tempo, e nada prejudica a inocência e a ternura dos primeiros idílios do adolescente, paradigmas da história de nossa adolescência, pelo menos até a época do cinema americano.

Mantém-se tão naturalmente a atmosfera de boa-fé, que o leitor resiste até o fim, ao lado de Bentinho, em admitir afinal o desenlace. É que nada foi omitido para alimentar essa atmosfera e prolongá-la; os menores detalhes foram prevenidos, como acontece com o capítulo "O retrato", posto simplesmente para funcionar mais adiante como um freio à nossa descoberta da verdade, quando Ezequiel começa a revelar a sua semelhança com Escobar. No capítulo referido, Gurgel, olhando o retrato da esposa morta, afirma que Capitu é a sua cópia, e, como não há nenhuma relação de consanguinidade, comenta: "Na vida há dessas semelhanças esquisitas." Muito mais tarde, quando as semelhanças de Ezequiel ameaçam romper brutalmente o ambiente de 
boa-fé, essa passagem opera como um amortecedor da impressão, porque, afinal, existem na vida semelhanças inexplicáveis.

O capítulo "O contrarregra" é um modelo de dosagem das circunstâncias e dos elementos psicológicos para formar um ambiente enigmático de adivinhações, de pressentimentos, impedindo, contudo, que se localizem. É o primeiro encontro de Escobar com Capitu, que coincide com a passagem, pela rua, do rapaz a cavalo. Postos em contato os três que o destino vai envolver nas suas malhas - Bentinho, Capitu, Escobar -, provoca-se uma crise de intolerância, reações desordenadas que vão ser descarregadas por Bentinho sobre o rapaz do cavalo, simples figurante sem a menor significação. Todos ficam tateando na sombra, e nós com eles, farejando, mas incapazes de localizar a ofensiva do destino.

A história vai sendo contida e retardada, como uma vasta e meticulosa preparação à ação rápida e súbita dos últimos capítulos, espécie de golpe de misericórdia na felicidade de Bentinho e até na do leitor. A verdadeira ação, o "conto" do Dom Casmurro, está concentrada nessas páginas finais, que nos colocam diante do irremediável.

Mas Capitu ainda nos reserva uma surpresa, da maior importância, porque não nos permite, nem a Bentinho, atenuar a força catártica desse irremediável, compreendendo o fato como uma simples leviandade, em que Escobar e ela se identificassem àquelas duas criaturas "sem ocupação nem sentimentos" de $O$ primo Basílio. Não podemos escapar, por essa tangente, à crueldade do fato, porque a figura de Capitu avulta, e o seu caso se revela subitamente sério, diante do cadáver de Escobar: "A confusão era geral. No meio dela, Capitu olhou alguns instantes para o cadáver, tão fixa, tão apaixonadamente fixa, que não admira lhe saltassem algumas lágrimas, poucas e caladas [...]" (capítulo CXXIII) Machado não deixa relaxar a tensão com essa facilidade, e acumula ainda sobre Bentinho outros motivos de distorção da alma, que era cândida e dificilmente se resignou a essa negação do passado, não pedindo até o fim outra coisa "senão a plena justificação de Capitu", e abraçando aflito a cabeça de Ezequiel, a quem, apesar de tudo, amava como a um filho.

Machado realizou no Dom Casmurro a sua concepção de arte; procurou a dor moral, que, só ela, cria o poder catártico da tragédia, sem olhar os elementos de que se 
socorria. O livro eleva a matéria local, anedótica e vulgar, a um plano verdadeiramente trágico, em que o destino, no sentido antigo, se realiza como uma força cega, triturando a inocência ou o vício, indiferentemente.

Dom Casmurro é um apogeu que não foi ultrapassado. Nada existe nele de supérfluo, a expressão é justa e perfeita, a substância é densa, todos os personagens valem e vivem por si. O livro representa bem a medida da perfeição machadiana, que ele andou ampliando ou restringindo até conseguir aqui a exata dimensão de seu modo criador.

Esaú e Jacó, por isso, aparece como um divertimento, um livro um pouco árido, embora conserve o equilíbrio e a superioridade de toque que ele adquirira. É a procura de uma nova direção, naquele espírito que não queria repetir-se, e de que surge a esplêndida figura do Aires, que vai se fixar no Memorial.

Ele se contenta muitas vezes em fazer exercícios de composição, como no capítulo XIII, em que se diverte a explicar a sua técnica literária. É um estilo em procura de assunto. Espera, e enquanto espera vai escrevendo, certo de que já hoje tudo o que lhe sai da pena tem pelo menos graça.

Quando retrata Natividade, acode-lhe sem esforço o velho senso do feminino corpo e alma - em passagens como a do capítulo IV. O mesmo acontece quando trata de Flora, conseguindo aquele capítulo fino e precioso denominado "Transfusão", ou o de sua morte, grave e comovente, com aquela fusão final dos dois gêmeos no pensamento da moribunda:

- Quem é? - perguntou Flora, ao vê-la tornar ao quarto.

- São os meus filhos que queriam entrar ambos.

- Ambos quais? - perguntou Flora.

Esta palavra fez crer que era o delírio que começava.

O estudo dos gêmeos semelhantes e opostos, das simetrias e desavenças que daí resultam, o registro de traços de nossa psicologia política, o estupendo Aires, a graça discreta de tudo, dão a esse exercício uma qualidade superior. 
No capítulo "Um Eldorado" reponta o cronista dos fatos do tempo, e na história da cartomante, e dos $2 \$ 000$ para a missa das almas, ressuscita o velho Machado dos contos. Todos os seus avatares marcaram aqui um encontro, para se despedirem, ou para se conjurarem em algum novo empreendimento conjunto. Como quer que seja, é uma pausa, e sente-se que Machado cochila, boceja e esperta de vez em quando, travestido no autor das "Primas de Sapucaia!", de Brás Cubas, ou mesmo num cronista social e político de outra era. E cada vez que esperta é para apressar um pouco o romance e dizer uma coisa fina, uma observação penetrante, ou uma simples pilhéria discreta e cordial. Nota-se sobretudo o desejo de esmiuçar a nossa psicologia política, e de se envolver um pouco nos acontecimentos. O inventário que nos deixou, nesse sentido, é pouco lisonjeiro para nós e até para o continente. Veja-se a cena de uma reação popular, no capítulo XXXIX, e esta outra, em Caracas (capítulo XL):

- Que rumor é este, Carmen? - perguntou ele entre duas carícias.

- Não se assuste, amigo meu; é o governo que cai.

- Mas eu ouço aclamações...

- Então é o governo que sobe. Não se assuste. Amanhã é tempo de ir cumprimentá-lo.

E além ele tudo ainda temos o Aires. Esse Aires é um fino tagarela, e eu gostaria muito de conhecê-lo. Já para o fim da vida declarava esse antigo diplomata que tinha perdido até o vício da desconfiança - "mas, se me aposentei, foi justamente para crer na sinceridade dos outros. Que os efetivos desconfiem." (Memorial, 08.05.1889) -, o que não era verdade. Mas com toda a sua desconfiança e a sua tagarelice, era o delicioso tipo de homem que Machado teria desejado ser.

Em Esaú e Jacó já ele nos aparece com a mulher enterrada em Viena e diversas reminiscências sepultadas em outras partes do mundo, indulgente e caricioso no manejo das criaturas, apesar de uma informação tendenciosa que o escritor nos dá a seu respeito: "Não é que falasse mal de ninguém, e aliás seria uma distração. Quero crer que não dissesse mal por indiferença ou cautela; provisoriamente, ponhamos caridade." (XXXVIII) 
Esse Aires amigo das reminiscências, fiel a um antigo amor a Natividade, e que aceitou, em nome disso, um encargo de "paternidade espiritual" sobre os seus gêmeos; esse humanista que os definia com os atributos dos heróis de Homero; "que também gostava de estudar adágios" como passatempo; que acompanhou com os olhos enternecidos e vivazes o caso de Flora, a "inexplicável", como o fará depois com Fidélia, diz-nos muito mais sobre a sensibilidade de Machado do que outros de seus porta-vozes.

Esse Aires ama os contornos desta cidade de São Sebastião, e até antecipa as suas futuras modificações, fazendo profecias e protestando de antemão contra a mudança de um quadro que emoldurou o seu passado:

A enseada não difere de si. Talvez os homens venham algum dia atulhá-la de terra e pedras para levantar casas em cima, um bairro novo, com um grande circo destinado a corrida de cavalos. Tudo é possível debaixo do sol e da lua. A nossa felicidade, barão, é que morreremos antes. (capítulo L)

É esse Aires, por fim, que nós viremos conhecer mais intimamente no Memorial. Parece à primeira vista que Machado adotou aqui aquele processo de escrever que aconselhava a Mário de Alencar, em carta de 18 de março de 1907: "Ideias fugitivas, quadros passageiros, emoções de qualquer espécie, tudo são cousas que o papel aceita e a que mais tarde se dá método, se lhes não convier o próprio desalinho". (Correspondência, p. 260.)

Isso, porém, seria uma ilusão: o Memorial é uma renda finíssima, minuciosamente tecida. Notava-lhe Mário de Alencar um caráter que o distingue dos outros, "uma parte grande e admirável, que é efeito da colaboração de um sentimento novo, o mesmo que fez o soneto 'A Carolina' e que nessas páginas traçou aquela figura verdadeira e sagrada de D. Carmo". (Correspondência, p. 272.)

Com efeito, depois da morte da mulher, o escritor encanecido apresenta sinais evidentes de ruptura no equilíbrio tranquilo que vinha sustentando. As suas cartas a amigos como Mário e Nabuco repercutem já como apelos. Esse de quem Nabuco dizia que podia guardar o fel para os seus romances, mas como homem era feliz "e vivia na beatitude", sente-se desgarrado, inquieto, enviando mensagens de socorro, embora muito discretas. Pede-lhe que não o esqueça, que ele, Machado, "não esqueceria o 
amigo que viu adolescente". Entra num estado de inquietação para a qual não estava preparada a sua alma, que sofrera as devastações da crítica bíblica do tipo Renan, tão medíocre depois de refutada, quanto insidiosa no seu surto, drama espiritual recentemente reproduzido no admirável livro de Mallègue.

Apega-se, então, com a maior angústia, àqueles penhores de perduração na memória dos homens, como o ramo de carvalho que lhe linha sido oferecido em uma sessão da Academia. Pede "que esta o conserve, como lembrança de nós três: Você [Nabuco], o Graça e eu", como se esse movimento de refúgio nos braços dos amigos e da glória pudesse realmente restituir-lhe a atitude de desafio do mendigo de Quincas Borba, que olhava o céu no largo do Rossio.

As suas suscetibilidades e pudores se exasperam, e ele recomenda insistentemente a Mário de Alencar "que, a respeito do modelo de Carmo, nada confie a ninguém; fica entre nós dois" (Correspondência, p. 288).

Não sei até que ponto Machado endossou a declaração de Aires, logo no início do Memorial: "Quando eu morrer, irei para onde ela estiver, no outro mundo, e ela virá ao meu encontro" (12.01.1888); mas é evidente que se capacitou desde logo desta outra, no fim daquelas memórias: "Já não sou deste mundo, mas não é mau afastar-se a gente da praia com os olhos na gente que fica." (15.05.1889).

A vida do casal Aguiar foi mesmo um olhar retrospectivo lançado sobre a felicidade, a simples felicidade "diminuída" que ele viveu, espantado de que fosse tão simples: "É só isto, nada mais que isto. Viveram até hoje sem bulha nem matinada." (04.02.1888)

Machado personifica no Memorial os dois aspectos mais importantes de sua personalidade: o escritor e o marido de Carolina. O primeiro, última fotografia de sua alma, no estado em que a deixou essa longa diplomacia da vida e da literatura, é o velho conselheiro Aires, inquieto, curioso, fino, nunca desligado do sentimento de sua terra, apesar das viagens imaginárias através de outras culturas, carregando atrás de si um séquito de reminiscências, de sabedoria experiente, não propriamente amarga, mas melancólica. O segundo foi a sua parte estável, aquela que soube ser feliz, à força de circunscrever as excentricidades do outro ao terreno da pura ficção. O seu anjo burguês domesticou o seu demônio aristocrático; puderam conviver em boa camaradagem, e os 
poucos atritos que tiveram foram inofensivos como num desenho animado de Walt Disney. Ambos tinham essa mesma simplicidade: o anjo de Carolina com a sua coroazinha natural, o demônio do espírito com a sua capa vermelha e a sua cauda trêfega, que tanto amedrontaram os contemporâneos.

No fundo tudo não passou de um compromisso recíproco em benefício de uma terceira coisa, da obra que ele tinha que realizar e que foi a sua mais alta experiência. Ainda ela é o grande refúgio, nesses últimos anos de solidão, e agora é tanto mais amiga quanto já não lhe exige o grande esforço do início. Encontramos no Memorial uma integração absoluta de suas aquisições; ele realiza a reabsorção de todos os elementos técnicos, de tal forma, que a técnica deixa de se interpor entre o sentimento e o leitor, se apaga, se anula, torna-se translúcida e deixa-se atravessar como um meio elástico e incolor para nos oferecer um contato direto com o sentimento em estado de nascença.

O que Machado nos quis exprimir durante toda a vida foi esse inexprimível, essa pura música interior, toda feita de tons esbatidos e de frêmitos pudicos. Isso é algo de essencial, inerente à nossa sensibilidade; é essa queixa velada que alimentou, como um filão oculto, a nossa grande poesia romântica, e que circula novamente, sempre que entre nós a poesia retoma a sua inspiração genuína. É como se o antirromântico que foi Machado de Assis não tivesse feito mais do que desbastar na nossa psicologia tudo o que no romantismo foi desordem alienígena, para afinal nos restituir à delicadeza de nossa sensibilidade, essa coisa fina e melindrosa que chegou a caracterizar a nossa cultura incipiente, a emprestar aos nossos costumes um tom de cordialidade específica, abrandar a aspereza de instituições transplantadas e constituir-se obscuramente, ao longo de nossa história, num antídoto seguro a todas as nossas múltiplas intemperanças.

Foi assim que Machado sentiu a vocação de nosso povo; foi por isso que ele reagia, com um sistema complicado de reflexos, a tudo quanto ameaçasse deformar essa fisionomia do Brasil. Olhava para o passado recente, onde lhe parecia que os seus traços genuínos começavam a acentuar os seus contornos, naquela sociedade dos salões, das chácaras de Botafogo, do Teatro Lírico, do velho Senado, que ele deixou fixado naquela grande página, que nunca se lê sem um pouco de nostalgia de nós mesmos. Mas pressentia o futuro, que já começava a agitar-se, e foi um espírito ao encontro do século XX, 
e não viu nada de bom nessas gerações que iam surgir, portadoras de rupturas internas que ele descobriu e dissecou.

E porque não era um apóstolo, limitou-se a lançar sobre nós todos um olhar indulgente, mas desconfiado. 